\title{
Dynamics of $\mathrm{Ca}^{2+}$ and guanosine $5^{\prime}$-[ $\gamma$-thio $]$ triphosphate action on insulin secretion from $\alpha$-toxin-permeabilized HIT-T15 cells
}

\author{
Jean-Christophe JONAS, ${ }^{\star} \ddagger$ Guodong LI, ${ }^{\star}$ Michael PALMER, $\dagger$ Ulrich WELLER $\dagger$ and Claes B. WOLLHEIM^§ \\ *Division de Biochimie Clinique, Département de Médecine, Centre Médical Universitaire, CH-1211 Genève 4, Switzerland, \\ and †Institut für Medizinische Mikrobiologie, University of Mainz, Hochhaus am Augustusplatz, D-55131 Mainz, Germany.
}

\begin{abstract}
The time course of $\mathrm{Ca}^{2+}$ and GTP-analogue effects on insulin secretion was investigated in HIT-T15 cells permeabilized with Staphylococcus $\alpha$-toxin. These cells responded to $\mathrm{Ca}^{2+}$ in the range $0.1-10 \mu \mathrm{M}$ and could be used in a dynamic perifusion system because of the minimal run-down of the secretory response. High $\mathrm{Ca}^{2+}(10 \mu \mathrm{M})$ elicited a monophasic ATPdependent stimulation of insulin secretion that reached a peak within $5 \mathrm{~min}$ ( 20-fold increase) and rapidly decreased during the subsequent $15 \mathrm{~min}$ to a plateau remaining above basal rates $\left(0.1 \mu \mathrm{M} \mathrm{Ca}^{2+}\right)$. The decrease in $\mathrm{Ca}^{2+}$-induced insulin secretion with time could not be attributed to decreased capacity to respond to $\mathrm{Ca}^{2+}$ after prolonged perfusion at low $\mathrm{Ca}^{2+}$ (rundown), nor to depletion of a particular secretory-granule pool. It was rather due to desensitization of the secretory machinery to $\mathrm{Ca}^{2+}$ that was not reversed by selective inhibition of the $\mathrm{Ca}^{2+}$ / calmodulin-dependent kinase II with $\mathrm{KN}-62$. However, an
\end{abstract}

intermediate $\mathrm{Ca}^{2+}$ concentration $(2 \mu \mathrm{M})$ increased insulin secretion to stable level without causing any desensitization. Imposed oscillations of $\mathrm{Ca}^{2+}(0.1-10 \mu \mathrm{M})$ produced phasic oscillations of insulin secretion, but did not prevent desensitization to $\mathrm{Ca}^{2+}$. Poorly hydrolysable GTP analogues increased insulin secretion at low $\mathrm{Ca}^{2+}$, whereas they strongly inhibited $\mathrm{Ca}^{2+}$. induced insulin secretion. By contrast, GTP did not affect basal secretion, and slightly increased $\mathrm{Ca}^{2+}$-evoked secretion. These results indicate the following. (1) Oscillations of insulin secretion are tightly coupled to cytosolic $\mathrm{Ca}^{2+}$ oscillations. (2) Oscillations of $\mathrm{Ca}^{2+}$ do not prevent high- $\mathrm{Ca}^{2+}$-induced desensitization to $\mathrm{Ca}^{2+}$; this result does not support the idea of a greater efficiency of oscillations compared with sustained $\mathrm{Ca}^{2+}$ rises in triggering exocytosis. (3) Activation of G-proteins modulates exocytosis in a bimodal manner.

\section{INTRODUCTION}

Permeabilized-cell models have been widely used to study the molecular requirements of exocytosis in a variety of cell types (for reviews see Gomperts, 1990; Burgoyne and Morgan, 1993), including insulin-secreting cells (Jones et al., 1985; Vallar et al., 1987). Although ATP-dependency and $\mathrm{Ca}^{2+}$-sensitivity are general properties of exocytosis in these models, the effects of guanine nucleotides greatly depend on the cell type, the size of pores generated by the permeabilization technique and the ionic composition of the medium (Knight et al., 1989; Ahnert-Hilger et al., 1992a,b; Burgoyne and Morgan, 1993).

In insulin-secreting cells (HIT-T15, RINm5F) permeabilized by high-voltage discharge or the pore-forming toxin streptolysin$\mathrm{O}$, exocytosis can be triggered either by $\mathrm{Ca}^{2+}$ or by poorly hydrolysable GTP analogues in a $\mathrm{Ca}^{2+}$-independent manner (Vallar et al., 1987; Li et al., 1993a). Since these results were obtained in short-term $(5-15 \mathrm{~min})$ static incubations, little is known about the dynamics of $\mathrm{Ca}^{2+}$ - and guanine-nucleotideinduced insulin secretion in permeabilized cells. In particular, the interaction of these agents in a dynamic system could provide important information about the hierarchy of events controlling secretion.

In dynamic experiments with intact pancreatic islets, glucose triggers a biphasic increase in insulin secretion. Measurement of cytosolic free $\mathrm{Ca}^{2+}$ concentration $\left(\left[\mathrm{Ca}^{2+}\right]_{\mathrm{i}}\right)$ by microspectrofluorimetry has revealed a similar pattern of $\left[\mathrm{Ca}^{2+}\right]_{1}$ rise in response to glucose (Santos et al., 1991; Gilon and Henquin, 1992). During the second phase, fast and/or slow $\left[\mathrm{Ca}^{2+}\right]_{i}$ oscillations (frequency of $\sim 2-3 / \mathrm{min}$ and $0.2-0.5 / \mathrm{min}$ respectively) have been reported in intact pancreatic islets (Valdeomillos et al., 1989; Longo et al., 1991; Gilon and Henquin, 1992) and in single pancreatic $\beta$-cells (Pralong et al., 1990; Herchuelz et al., 1991; Theler et al., 1992). Similarly, oscillations of insulin secretion were observed in single islets from $o b / o b$ mice and rats (Opara et al., 1988; Longo et al., 1991; Bergsten and Hellman, 1993). However, the role of $\left[\mathrm{Ca}^{2+}\right]_{i}$ oscillations in glucose-induced insulin secretion has not yet been clarified. For instance, it is still unclear whether $\left[\mathrm{Ca}^{2+}\right]_{i}$ oscillations are more efficient at stimulating insulin secretion than is a sustained elevation of $\left[\mathrm{Ca}^{2+}\right]_{\mathrm{i}}$.

Thus the aim of this study was to characterize the dynamics of $\mathrm{Ca}^{2+}$ and GTP-analogue-induced insulin secretion in permeabilized cells. We also evaluated whether oscillations of $\mathrm{Ca}^{2+}$ (i) produce phasic oscillations of insulin secretion; and/or (ii) would favour a sustained second phase of insulin secretion. We therefore used Staphylococcus aureus $\alpha$-toxin to permeabilize HIT-T15 insulin-secreting cells.

The mechanism of pore formation by $\alpha$-toxin has been well characterized (for review, see Bhakdi and Tranum-Jensen, 1991). Briefly, water-soluble $\alpha$-toxin monomers $(34 \mathrm{kDa})$ attach to the plasma membrane and, by hexamerization, form pores of 1$2 \mathrm{~nm}$ diameter. These pores allow the free passage of molecules $\leqslant 2-3 \mathrm{kDa}$, while preventing cytosolic protein leakage from cells. Similarly, $\alpha$-toxin monomers do not enter cells, and leave intracellular membranes intact. This toxin, like other poreforming toxins, has been successfully used to permeabilize a variety of cell types, including chromaffin, PC12 and RIN A2

Abbreviations used: GTP[S], guanosine $5^{\prime}-[\gamma$-thio $]$ triphosphate; $[\mathrm{NH}] \mathrm{ppG}$, guanosine $5^{\prime}$-[ $\beta \gamma$-imido]triphosphate; $\left[\mathrm{Ca}^{2+}\right]_{\mathrm{i}}$, cytosolic free $\mathrm{Ca}^{2+}$ concentration; CaM kinase II, $\mathrm{Ca}^{2+} /$ calmodulin-dependent protein kinase II; $\mathrm{LDH}$, lactate dehydrogenase.

¥ Present address: Endocrinologie et Métabolisme, Université Catholique de Louvain, Tour Harvey 55.30, B-1200 Bruxelles, Belgium.

$\S$ To whom correspondence should be addressed. 
cells (Ahnert-Hilger et al., 1985; Bader et al., 1986; Lind et al., 1987). Using $\alpha$-toxin, we obtained permeabilized HIT cells that retain the ability to respond to $\mathrm{Ca}^{2+}$ for an extended period, allowing their use in a dynamic system.

\section{EXPERIMENTAL}

\section{Materials}

ATP, GTP, guanosine $5^{\prime}$-[ $\gamma$-thio]triphosphate (GTP[S]) and guanosine $5^{\prime}$-[ $\beta \gamma$-imido]triphosphate $(\mathrm{p}[\mathrm{NH}] \mathrm{ppG})$ were purchased from Boehringer Mannheim, Mannheim, Germany. Stock solutions of guanine nucleotide analogues were prepared in $20 \mathrm{mM}$ Hepes buffer, pH 7.0. KN-62 was supplied by Dr. H. Hidaka, Nagoya University School of Medicine, Nagoya, Japan.

\section{$\alpha$-Toxin}

Staphylococcus aureus $\alpha$-toxin was purified as described by Palmer et al. (1993) and reconstituted at a concentration of $3.6 \mathrm{mg} / \mathrm{ml}$ in $10 \mathrm{mM}$-phosphate-buffered saline (PBS), $\mathrm{pH} \mathrm{7.0,}$ containing $1 \mathrm{mg} / \mathrm{ml} \mathrm{BSA}$. The haemolytic activity of the toxin was determined in duplicate by using rabbit erythrocytes (Lind et al., 1987). Briefly, heparin-treated rabbit erythrocytes were washed twice and diluted 1:40 with ice-cold PBS. This $2.5 \%$ erythrocyte solution was then mixed with a serial dilution of $\alpha$ toxin and incubated for $45 \mathrm{~min}$ at $37^{\circ} \mathrm{C}$. Total and non-specific haemolyses were determined in PBS alone or supplemented with $0.2 \%(w / v)$ SDS. After centrifugation for $2 \mathrm{~min}$ at $12000 \mathrm{~g}$, $30 \mu \mathrm{l}$ of supernatant was diluted in $1 \mathrm{ml}$ of water, and released haemoglobin was measured spectrophotometrically at $412 \mathrm{~nm}$. The dilution of $\alpha$-toxin that produces $50 \%$ haemolysis of red cells $\left(\mathrm{EC}_{50}\right)$ was determined, and the reciprocal of this value was taken as the number of haemolytic units (H.U.) in $1 \mathrm{ml}$ of the undiluted $\alpha$-toxin solution. On average, the haemolytic activity of the toxin was $58000 \pm 7800 \mathrm{H} . \mathrm{U} . / \mathrm{mg}(n=6)$.

\section{Cells}

HIT-T15 cells (passages 71-79) were cultured in RPMI 1640 medium supplemented as described by Regazzi et al. (1990).

\section{Permeabilization of attached cells and static insulin-release experiments}

HIT-T15 cells were cultured for 2 days in microtitre plates at an initial density of $10^{5}$ cells/well. Before use, the cells were washed twice with a $\mathrm{Ca}^{2+}$-free modified Krebs-Ringer medium [buffer A,

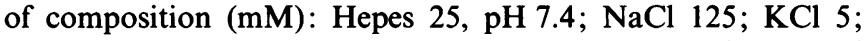
$\mathrm{MgSO}_{4} 2 ; \mathrm{KH}_{2} \mathrm{PO}_{4} 1.2$; EGTA 0.4 ; glucose 6 ; and $1 \mathrm{mg} / \mathrm{ml}$ BSA]. They were then permeabilized during $10 \mathrm{~min}$ at $37^{\circ} \mathrm{C}$ with $\alpha$-toxin $(1000 \mathrm{H} . \mathrm{U} . / \mathrm{ml})$ dissolved in buffer $\mathrm{G}$ [composition $(\mathrm{mM})$ : Hepes 20, pH 7.0; potassium glutamate $140 ; \mathrm{NaCl} 5$; $\mathrm{MgSO}_{4} 7$; $\mathrm{Na}_{2} \mathrm{ATP} 5$; EGTA 10.2] with sufficient $\mathrm{CaCl}_{2}$ to give a free $\mathrm{Ca}^{2+}$ concentration of $0.1 \mu \mathrm{M}$. Cell permeabilization was assessed by eosin and Trypan Blue dye-uptake tests. Under these conditions, HIT cells did not detach from the well, and $95-100 \%$ of cells were permeable to eosin $(624 \mathrm{kDa})$, whereas $15-20 \%$ of cells were coloured by Trypan Blue $(960 \mathrm{kDa})$. A higher toxin concentration resulted in pronounced cell detachment from the well. Only a few (less than $5 \%$ ) control cells incubated without $\alpha$-toxin were stained with either dye.

The activity of lactate dehydrogenase (LDH; $\sim 140 \mathrm{kDa})$, used as a marker for cytosolic proteins, was assessed in supernatants and cell lysates of $\alpha$-toxin-permeabilized cells by a modification of the method described by Kornberg (1955). Briefly, the rate of consumption of NADH $(20 \mu \mathrm{M})$ induced by a sample was measured in the presence of $2 \mathrm{mM}$ pyruvate, $0.5 \mathrm{mg} / \mathrm{ml}$ BSA and $20 \mathrm{mM}$ Hepes, $\mathrm{pH} 7.2$, with a fluorescence spectrometer (excitation/emission wavelengths: $340 / 460 \mathrm{~nm}$ ). The total LDH content was similar in control and treated cells [ $36 \pm 1.3$ and $35.7 \pm 1.6$ m-units/well $(n=6)$ respectively], and no LDH activity could be detected in supernatants (the limit of LDH detection using this assay was approx. $5 \%$ of cellular content).

After cell permeabilization, the medium was replaced for a 5 min incubation period by test medium (buffer $\mathrm{G}$ containing 0.1 , 2 or $10 \mu \mathrm{M}$ free $\mathrm{Ca}^{2+}$ and test substances). The amount of insulin secreted into the medium was assessed by radioimmunoassay, with human insulin as standard (Praz et al., 1983).

\section{Permeabilization of cells in suspension and dynamic insulin-release experiments}

On the day of the experiment, HIT-T15 cells were detached and transferred to spinner culture (Wollheim and Pozzan, 1984). After $3 \mathrm{~h}$, the cells were washed twice in buffer $A$ and resuspended at a concentration of $20 \times 10^{6}$ cells $/ \mathrm{ml}$ in buffer $\mathrm{E}$ [buffer $\mathrm{G}$, containing instead (mM): $\mathrm{MgSO}_{4} 4, \mathrm{Na}_{2} \mathrm{ATP} 2$ and EGTA 0.2 ; free $\mathrm{Ca}^{2+}$ approx. $0.1 \mu \mathrm{M}$ ]. This cell suspension was mixed $1: 1$ (v/v) with buffer E supplemented with $\alpha$-toxin and incubated for $10 \mathrm{~min}$ at $37^{\circ} \mathrm{C}$ at a final concentration of $3500 \mathrm{H} . \mathrm{U} . / 10^{7}$ cells per $\mathrm{ml}$. After centrifugation $\left(5 \mathrm{~min}\right.$ at $\left.1000 \mathrm{~g}, 4^{\circ} \mathrm{C}\right)$, the supernatant was discarded and cells were resuspended in buffer $\mathrm{E}$ $\left(40 \times 10^{6}\right.$ cells $\left./ \mathrm{ml}\right)$. With this protocol, $97-100 \%$ of cells were permeable to Trypan Blue (control cells: $9.9 \pm 1.2 \%, n=27$ ), and remained so for at least $2 \mathrm{~h}$ at $37^{\circ} \mathrm{C}$.

Permeabilized cells were transferred to perifusion chambers ( $100 \mu \mathrm{l}, 4 \times 10^{6}$ cells; filter of $8 \mu \mathrm{m}$ pore size) and were continuously perfused with buffer $\mathrm{G}$ (but containing $4 \mathrm{mM} \mathrm{MgSO}_{4}$, $2 \mathrm{mM} \mathrm{Na}_{2}$ ATP) at a flow rate of $\sim 600 \mu \mathrm{l} / \mathrm{min}$, unless otherwise specified. After an initial $10 \mathrm{~min}$ washing period, effluent fractions were collected every $2 \mathrm{~min}$, diluted with glycine buffer containing BSA (final concn. $\sim 1 \mathrm{mg} / \mathrm{ml}$ ) and kept at $-20^{\circ} \mathrm{C}$ until insulin assay. Before perifusion, a sample of permeabilized cell suspension was taken for measurement of insulin content.

\section{$\mathrm{Ca}^{2+}$ concentration}

The free $\mathrm{Ca}^{2+}$ concentrations in buffer $\mathrm{G}$ were measured with a $\mathrm{Ca}^{2+}$ electrode (Prentki et al., 1983) and corresponded to those calculated from the appropriate equilibrium constants (Sillén and Martell, 1964).

\section{Statistical analysis}

Results are expressed as means \pm S.E.M. for the indicated number of experiments. The statistical significance of differences between groups was assessed by Student's $t$ test.

\section{RESULTS}

\section{Static insulin secretion}

$\alpha$-Toxin-permeabilized HIT-T15 cells incubated in the presence of $5 \mathrm{mM}$ ATP at low free $\mathrm{Ca}^{2+}$ concentration $(0.1 \mu \mathrm{M})$ secreted $2.67 \pm 0.17 \%$ of their insulin content in $5 \mathrm{~min}(n=12)$. This cell preparation was highly responsive to $\mathrm{Ca}^{2+}$, since $2 \mu \mathrm{M}$ and $10 \mu \mathrm{M}$ free $\mathrm{Ca}^{2+}$ applied directly after cell permeabilization produced a 6 - and 10-fold increase in insulin secretion respectively $(5.98 \pm 0.39$ and $9.73 \pm 0.47$ versus $0.98 \pm 0.05 \mathrm{ng} /$ well per $5 \mathrm{~min}$; 
Table 1 Run-down of $\mathrm{Ca}^{2+}$-stimulated insullin secretion from $\alpha$-toxinpermeabilized HIT cells

Attached cells were permeabilized by incubation with $\alpha$-toxin for 10 min. Cells were then incubated for $5 \mathrm{~min}$ in a medium containing $0.1 \mu \mathrm{M} \mathrm{Ca}^{2+}$ or $10 \mu \mathrm{M} \mathrm{Ca}^{2+}$, either directly after cell permeabilization or after 10 or 20 min preincubation in the presence of $0.1 \mu \mathrm{M} \mathrm{Ca}^{2+}$. Values are means \pm S.E.M. for 12 observations from 3 independent experiments: ${ }^{*} P<0.01$ compared with control group (without preincubation).

\begin{tabular}{lll}
\hline & \multicolumn{2}{l}{ Insulin secretion (ng/well) } \\
\cline { 2 - 3 } $\begin{array}{l}\text { Preincubation } \\
\text { period }\end{array}$ & $0.1 \mu \mathrm{M} \mathrm{Ca}^{2+}$ & $10 \mu \mathrm{M} \mathrm{Ca}^{2+}$ \\
\hline- & $1.56 \pm 0.10$ & $10.3 \pm 0.72$ \\
$10 \min$ & $1.65 \pm 0.04$ & $7.54 \pm 0.65^{\star}$ \\
$20 \mathrm{~min}$ & $1.74 \pm 0.06$ & $6.47 \pm 0.41^{\star}$
\end{tabular}

$n=28)$. A $10 \mathrm{~min}$ preincubation of the permeabilized cells at $0.1 \mu \mathrm{M} \mathrm{Ca}{ }^{2+}$ before stimulation significantly decreased $\mathrm{Ca}^{2+}$ induced insulin secretion $(7.54 \pm 0.65$ versus $10.3 \pm 0.72 \mathrm{ng} /$ well in the control), as shown in Table 1 . No further decrease in $\mathrm{Ca}^{2+}$ induced insulin secretion occurred when preincubation at low $\mathrm{Ca}^{2+}$ concentration was prolonged to $20 \mathrm{~min}$. However, neither basal insulin secretion (Table 1) nor eosin-dye uptake was modified by the preincubation period.

We next evaluated the effects of GTP and its poorly hydrolysable analogues GTP[S] and p[NH]ppG on insulin secretion from $\alpha$-toxin-permeabilized cells. As shown in Figure 1, $100 \mu \mathrm{M}$ GTP[S] significantly increased insulin secretion in the presence of $0.1 \mu \mathrm{M} \mathrm{Ca}^{2+}$ and to a lesser extent in the presence of $2 \mu \mathrm{M} \mathrm{Ca}{ }^{2+}$, whereas it inhibited insulin secretion induced by $10 \mu \mathrm{M} \mathrm{Ca}^{2+}$ by $18.7 \pm 3.3 \%$. Qualitatively similar effects were observed with $100 \mu \overline{\mathrm{M}} \mathrm{p}[\mathrm{NH}] \mathrm{ppG}$. By contrast, $100 \mu \mathrm{M}$ GTP was completely ineffective on basal secretion, whereas it clearly potentiated $\mathrm{Ca}^{2+}$-induced insulin secretion in the presence of both 2 and $10 \mu \mathrm{M} \mathrm{Ca}^{2+}$.

The high responsiveness of $\alpha$-toxin-permeabilized HIT cells to $\mathrm{Ca}^{2+}$ and the small rundown of $\mathrm{Ca}^{2+}$-induced insulin secretion makes this permeabilized-cell preparation suitable for the study of insulin secretion in a dynamic perifusion system.

\section{Dynamic insulin secretion}

$\alpha$-Toxin-permeabilized HIT cells perifused with a medium containing $2 \mathrm{mM}$ ATP and a low free $\mathrm{Ca}^{2+}$ concentration $(0.1 \mu \mathrm{M})$ secreted $0.022 \pm 0.002 \%$ of insulin content $/ \mathrm{min}(n=12)$. The dynamic secretory response to $10 \mu \mathrm{M} \mathrm{Ca}^{2+}$ is shown in Figure 2(a). Typically, a 30 min stimulation with $\mathrm{Ca}^{2+}$ induced a rapid monophasic increase in insulin secretion that reached a peak within $5 \mathrm{~min}$ (20-fold increase), then gradually decreased and tended to stabilize at a level $\sim 3$ times higher than the basal level. The total $\mathrm{Ca}^{2+}$-induced insulin secretion (area under the curve) was $5.33 \pm 1.56 \%$ of insulin content $/ 30 \mathrm{~min}$, corresponding to an 8-fold increase in insulin secretion. Decreasing $\mathrm{Ca}^{2+}$ to $0.1 \mu \mathrm{M}$ after 10 min stimulation was followed by the return of insulin secretion to basal level within $10 \mathrm{~min}$ (Figure 2a). In this case, secretion was lower than in the continuous presence of $10 \mu \mathrm{M}$ $\mathrm{Ca}^{2+}(0.28 \pm 0.06$ and $0.69 \pm 0.2 \%$ of content from 40 to $50 \mathrm{~min}$, in the absence and presence of high $\mathrm{Ca}^{2+}$ respectively; $P=0.057$; $n=3)$. A second stimulation with $\mathrm{Ca}^{2+}$ still increased insulin release (Figure 2b). However, this $\mathrm{Ca}^{2+}$-induced insulin secretion was 2.6 times lower than that occurring during the first stimulation (applied after 40 or 20 min perifusion with low $\mathrm{Ca}^{2+}$ ). Thus the decrease in $\mathrm{Ca}^{2+}$-induced insulin secretion in the continuous presence of $\mathrm{Ca}^{2+}$ or during a second stimulation was not due to the run-down of the response to $\mathrm{Ca}^{2+}$, but rather to desensitization of the secretory machinery to $\mathrm{Ca}^{2+}$.

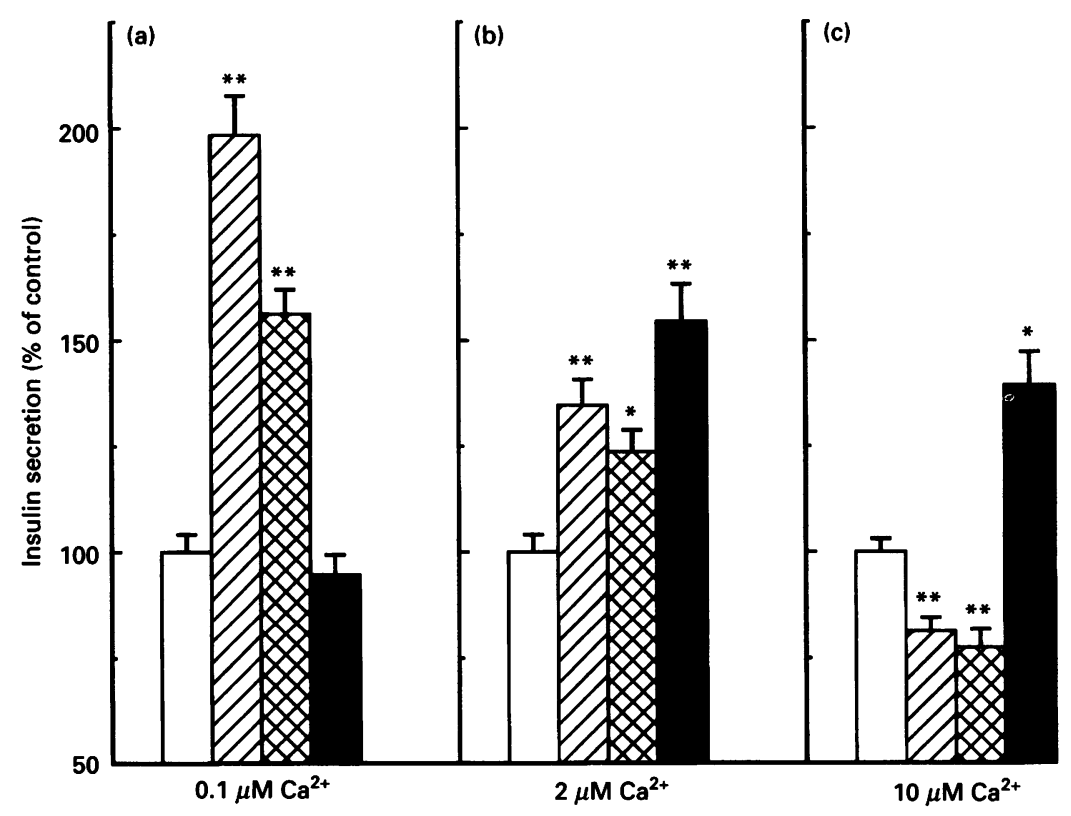

Figure 1 Effects of GTP analogues on insulin secretion from $\alpha$-toxin-permeabilized HIT cells

After permeabilization, cells were incubated for 5 min in a medium containing (a) $0.1 \mu \mathrm{M} \mathrm{Ca}^{2+}$, (b) $2 \mu \mathrm{M} \mathrm{Ca}^{2+}$ and (c) $10 \mu \mathrm{M} \mathrm{Ca}^{2+}$, alone ( $\square$ ) or supplemented with $100 \mu \mathrm{M} \mathrm{GTP}[\mathrm{S}]$ ( $\square$ ), $100 \mu \mathrm{M} \mathrm{p}[\mathrm{NH}] \mathrm{ppG}$ (因) or $100 \mu \mathrm{M} \mathrm{GTP}(\square)$. Control secretion in the presence of $0.1 \mu \mathrm{M}, 2 \mu \mathrm{M}$ and $10 \mu \mathrm{M} \mathrm{Ca}{ }^{2+}$ was $0.97 \pm 0.05,5.72 \pm 0.52$ and $9.57 \pm 0.62 \mathrm{ng} /$ well respectively. Values are means \pm S.E.M. for $8-12$ observations from 2-3 independent experiments: ${ }^{*} P<0.005$ and ${ }^{\star *} P<0.001$ compared with control. 


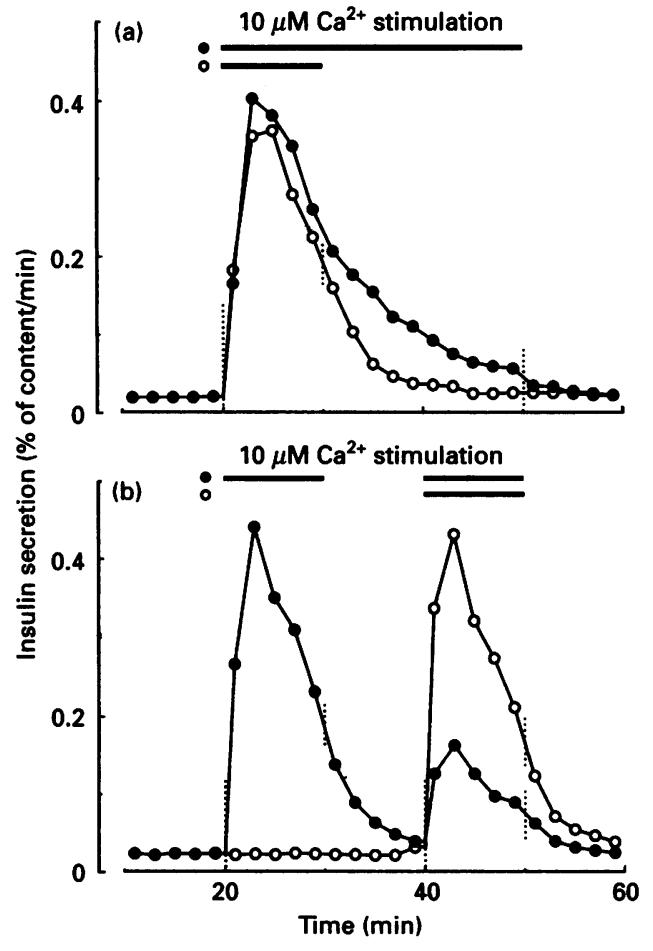

Figure 2 Dynamics of $\mathrm{Ca}^{2+}$-induced insulin secretion in $\alpha$-toxinpermeabilized HIT cells

Cells were permeabilized in suspension as described in the Experimental section and perifused during 20 min with basal medium $\left(0.1 \mathrm{mM} \mathrm{Ca}^{2+}\right)$. (a) Exocytosis was triggered by $10 \mu \mathrm{M} \mathrm{Ca}^{2+}$ during $10 \mathrm{~min}(\mathrm{O})$ or $30 \mathrm{~min}(\mathrm{O})$, as indicated by the horizontal lines. (b) A $10 \mathrm{~min}$ stimulation with $10 \mu \mathrm{M} \mathrm{Ca}{ }^{2+}$ was applied twice, from 20 to 30 and 40 to $50 \mathrm{~min}(O)$ or only once, from 40 to $50 \mathrm{~min}(\mathrm{O})$. Insulin secretion is expressed as a percentage of insulin content secreted per min, and results are corrected for dead volume of the perifusion system. Values are means for 3 experiments, and S.E.M. values are omitted for sake of clarity.

We next studied the ATP-dependency of $\mathrm{Ca}^{2+}$-induced insulin secretion. Cells were permeabilized in the absence of ATP, perifused with a medium containing 0 or $2 \mathrm{mM}$ ATP and stimulated during 30 min with high $\mathrm{Ca}^{2+}$. In the absence of ATP, basal secretion tended to be lower than in the presence of $2 \mathrm{mM}$ ATP $(0.12 \pm 0.03$ versus $0.24 \pm 0.07 \%$ of content $/ 10 \mathrm{~min} ; n=4$; $P=0.06$ by paired $t$ test). Under these conditions, $\mathrm{Ca}^{2+}$ stimulation failed to increase insulin secretion significantly above basal levels $(0.17 \pm 0.06$ versus $0.12 \pm 0.03 \%$ of content $/ 10 \mathrm{~min} ; n=4$; $P=0.16$ by paired $t$ test).

We then evaluated the effect of an intermediate $\mathrm{Ca}^{2+}$ concentration $\left(\mathrm{EC}_{50} \sim 2 \mu \mathrm{M}\right.$ in static incubation) on insulin secretion. Compared with $10 \mu \mathrm{M}, 2 \mu \mathrm{M} \mathrm{Ca}^{2+}$ caused a rapid and sustained increase in insulin secretion that was far less pronounced during the first $10 \mathrm{~min}$ (14- versus 36 -fold increase), but was nearly identical at the end of stimulation (Figure 3a). The total insulin secretion was about 2 times lower with $2 \mu \mathrm{M}$ than with $10 \mu \mathrm{M} \mathrm{Ca}^{2+}(3.19 \pm 0.4$ versus $6.24 \pm 0.91 \%$ of content/ $30 \min ; n=4)$.

We also compared pulsatile and continuous application of $10 \mu \mathrm{M} \mathrm{Ca}^{2+}$. Interestingly, oscillations of $\mathrm{Ca}^{2+}$ produced phasic oscillations of insulin secretion (Figure 3b). The first peak of insulin secretion was as high as that observed during sustained $\mathrm{Ca}^{2+}$ application. Nevertheless, there was a clear decrease in $\mathrm{Ca}^{2+}$ induced insulin secretion (area under the curve) from pulse to

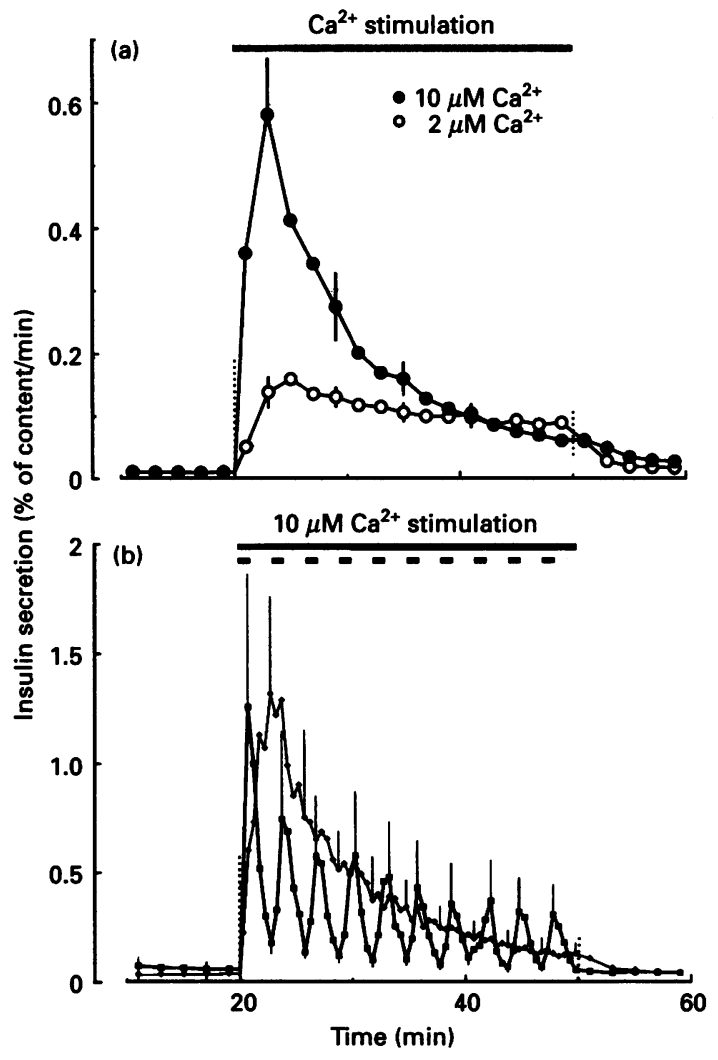

Figure 3 Effects of various patterns of $\mathrm{Ca}^{2+}$ addition on insulin secretion from $\alpha$-toxin-permeabilized HIT cells

After permeabilization, cells were peritused during 20 min with basal medium $\left(0.1 \mu \mathrm{M} \mathrm{Ca}^{2+}\right)$. (a) Exocytosis was then stimulated with $2 \mu \mathrm{M} \mathrm{Ca}^{2+}(\mathrm{O})$ or $10 \mu \mathrm{M} \mathrm{Ca}^{2+}$ (O). (b) $\mathrm{A} 10 \mu \mathrm{M}$ $\mathrm{Ca}^{2+}$ stimulus was applied either continuously ( $\bullet$, thin line) or in 1 min pulses every 3 min , thick line) during $30 \mathrm{~min}$, as indicated by the horizontal lines. In (a) and (b), cells were perfused at a flow rate of $\sim 1.2 \mathrm{ml} / \mathrm{min}$, to accelerate the exchange of medium in the perfusion chambers, and effluent fractions were collected every $30 \mathrm{~s}$, to increase the time resolution of the system. Insulin secretion is expressed as a percentage of insulin content secreted per min, and results are corrected for dead volume of the perifusion system. Results are means \pm S.E.M. for 3-4 experiments.

pulse (30 and $24 \%$ decrease from the first to the second and from the second to the third $\mathrm{Ca}^{2+}$ pulse respectively; $n=3$ ). This was not due to changes in $\mathrm{Ca}^{2+}$ stimulus itself, since peak and nadir $\mathrm{Ca}^{2+}$ levels were identical throughout the experiment (7$10 \mu \mathrm{M}$ and $0.1 \mu \mathrm{M} \mathrm{Ca}{ }^{2+}$ respectively), as assessed by $\mathrm{Ca}^{2+}$ measurement in $15 \mathrm{~s}$ effluent collections from parallel experiments performed without cells. From the third $\mathrm{Ca}^{2+}$ pulse on, insulin secretion induced by each $\mathrm{Ca}^{2+}$ pulse tended to stabilize (at about $30 \%$ of first pulse). Thus $\mathrm{Ca}^{2+}$ pulses were still capable of generating pulsatile insulin secretion. The peak insulin secretion in each transient during the first 15 min stimulation was roughly similar to the rate seen during continuous $\mathrm{Ca}^{2+}$ stimulation at corresponding time points. In contrast, during the last $15 \mathrm{~min}$ $\mathrm{Ca}^{2+}$ stimulation, the pulses produced higher rates of secretion (Figure 3b). However, during the last $10 \mathrm{~min}$, the mean insulin secretion was similar during pulsatile, sustained $2 \mu \mathrm{M}$ and $10 \mu \mathrm{M}$ $\mathrm{Ca}^{2+}$ stimulation $(0.91 \pm 0.19,1.01 \pm 0.05$ and $0.86 \pm 0.10 \%$ of content/10 min respectively; $n=3$ ). Hence, oscillations of $\mathrm{Ca}^{2+}$ do not prevent desensitization of the secretory machinery to $\mathrm{Ca}^{2+}$.

To evaluate the influence of low $\mathrm{Ca}^{2+}$-interval duration between pulses, three pulses of $\mathrm{Ca}^{2+}(2 \mathrm{~min})$ were applied at $14 \mathrm{~min}$ 


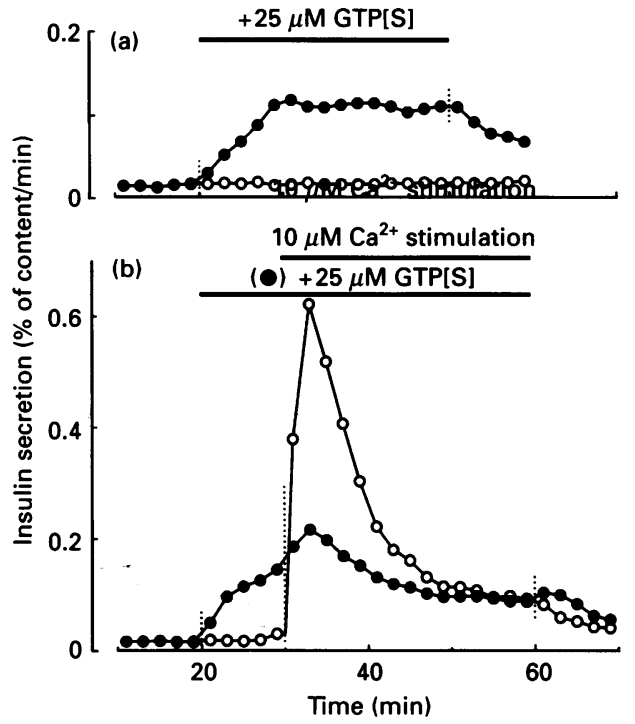

Figure 4 Dynamics of GTP[S] effects on basal and $\mathrm{Ca}^{2+}$-stimulated insulin secretion from $\alpha$-toxin-permeabilized HIT cells

(a) After permeabilization, cells were perifused with a medium containing $0.1 \mu \mathrm{M} \mathrm{Ca}^{2+}$ throughout the experiment $(\mathrm{O})$ or stimulated with $25 \mu \mathrm{M} \mathrm{GTP}[\mathrm{S}]$ as indicated by the horizontal line (O). (b) Cells were stimulated with $10 \mu \mathrm{M} \mathrm{Ca}^{2+}$ alone (O) or $10 \mu \mathrm{M} \mathrm{Ca}^{2+}$ and $25 \mu \mathrm{M}$ GTP[S], the latter being added 10 min before the $\mathrm{Ca}^{2+}$ stimulus $(\mathbf{O})$. Insulin secretion is expressed as a percentage of insulin content secreted per min, and results are corrected for dead volume of the perifusion system. Values are means for 3-6 experiments, and S.E.M. values are omitted for sake of clarity.

intervals. Under these conditions, $\mathrm{Ca}^{2+}$-induced insulin secretion gradually decreased from the first to the third pulse (30 and 36\% decreases from first to second and from second to third $\mathrm{Ca}^{2+}$ pulse respectively; $n=2$ ). Thus, no recovery of $\mathrm{Ca}^{2+}$ sensitivity occurred as time increased between the $\mathrm{Ca}^{2+}$ pulses.

We also used $\mathrm{KN}-62$, an inhibitor of $\mathrm{Ca}^{2+} /$ calmodulindependent protein kinase II (CaM kinase II) (Tokumitsu et al., 1990) to evaluate the role of the autophosphorylation of this enzyme in $\mathrm{Ca}^{2+}$-induced desensitization to $\mathrm{Ca}^{2+}$. $\mathrm{KN}-62(5 \mu \mathrm{M})$, applied $10 \mathrm{~min}$ before and also during $\mathrm{Ca}^{2+}$ stimulation, did not modify the dynamics of basal and $\mathrm{Ca}^{2+}(10 \mu \mathrm{M})$-evoked dynamic insulin secretion $(8.73 \pm 1.11 \%$ and $7.27 \pm 1.13 \%$ of content/ $30 \mathrm{~min}$ in the presence and absence of $\mathrm{KN}-62$ respectively; $n=5$ ). This is consistent with the inability of $\mathrm{KN}-62$ to affect $\mathrm{Ca}^{2+}$ stimulated insulin secretion during static incubation of electropermeabilized and streptolysin-O-permeabilized HIT-T15 cells reported previously ( $\mathrm{Li}$ et al., 1992). This result also reinforces the view that CaM kinase II may not be involved in the exocytosis elicited by $\mathrm{Ca}^{2+}$ in permeabilized insulin-secreting cells.

The effect of GTP[S] on basal and $\mathrm{Ca}^{2+}$-induced insulin secretion was also tested in dynamic experiments. As shown in Figure 4(a), $25 \mu \mathrm{M}$ GTP[S] clearly increased basal insulin secretion. Maximal effect (7-fold stimulation) was reached after 10 min and remained stable until GTP[S] was removed from the medium. Identical results (not shown) were obtained in the presence of a free $\mathrm{Ca}^{2+}$ concentration $<1 \mathrm{nM}$. Pre-exposure of cells to $25 \mu \mathrm{M}$ GTP[S] for $10 \mathrm{~min}$ resulted in an inhibition of subsequent $\mathrm{Ca}^{2+}$-induced insulin secretion by $87 \%$ (Figure $4 \mathrm{~b}$ ). The total increase in insulin secretion produced by $\mathrm{Ca}^{2+}$ (first $10 \mathrm{~min}$ ) in the absence and presence of GTP[S] was $4.20 \pm 0.65$ and $0.55 \pm 0.09 \%$ of content respectively $(n=6)$. By contrast,
$20 \mu \mathrm{M}$ GTP did not change basal insulin secretion and slightly increased $\mathrm{Ca}^{2+}$-induced insulin secretion, in agreement with results from static incubations. The latter effect, however, was transient, as it was limited to the first 5 min of secretion (results not shown).

\section{DISCUSSION}

The present study indicates that $\alpha$-toxin-permeabilized HIT-T15 cells are a good model to study the effect of low-molecular-mass substances on exocytosis in a dynamic perifusion system. The $\mathrm{Ca}^{2+}$-sensitivity of insulin secretion was in the range $0.1-10 \mu \mathrm{M}$ $\mathrm{Ca}^{2+}\left(\mathrm{EC}_{50} \sim 1-2 \mu \mathrm{M}\right.$ ), as described in other cell types (Knight et al., 1989; Holz et al., 1992) and in insulin-secreting cells permeabilized by other methods (Jones et al., 1985; Valler et al., 1987). The run-down of the response to $\mathrm{Ca}^{2+}$ was small and limited to the first 10-20 min after permeabilization, in contrast with the rapid run-down observed in streptolysin-Opermeabilized HIT cells ( $\mathrm{Li}$ et al., 1993a). This difference is probably due to the leakage of different cytosolic components from cells, as expected from the different diameter of pores generated by the two toxins $(1-2 \mathrm{~nm}$ for $\alpha$-toxin and $\geqslant 15 \mathrm{~nm}$ for streptolysin-O) (Bhakdi and Tranum-Jensen, 1987). Thus, PC12 and RIN A2 cells permeabilized with $\alpha$-toxin allowed the free passage of nucleotides, but not of LDH (Lind et al., 1987; Ahnert-Hilger et al., 1989). Similar results were obtained with HIT cells in the present study, as indicated by dye uptake, comparison of cell LDH content before and after permeabilization and the strict ATP-dependency of $\mathrm{Ca}^{2+}$-induced insulin secretion under dynamic conditions. This method of permeabilization, although yielding similar membrane pores, had some advantages over electroporation. First, we could easily permeabilize cells plated in 96 microwells, which is convenient for static incubations. Second, since cells did not reseal with time, we could perform lengthy dynamic experiments.

The typical time course of $\mathrm{Ca}^{2+}$-induced insulin secretion reported herein is similar to that described for electropermeabilized islets (Jones et al., 1992), except for much higher amplitude in the HIT cells (see below). Although insulin secretion was already severely decreased after $20 \mathrm{~min}$ of $\mathrm{Ca}^{2+}$ stimulation, the ion still enhanced the rate of secretion even beyond this time point, as indicated by the following observations. First, perfusion of cells with low $\mathrm{Ca}^{2+}(0.1 \mu \mathrm{M})$ at the end of the experiment produced a rapid decrease in insulin secretion to the baseline. Second, when $\mathrm{Ca}^{2+}$ was decreased after 10 min of stimulation, insulin secretion was lower than in the continuous presence of high $\mathrm{Ca}^{2+}$. In this case, a second stimulation with $\mathrm{Ca}^{2+}$ was followed by a second monophasic increase in insulin secretion, albeit of lower amplitude. Nevertheless, the decrease of insulin secretion in the presence of high $\mathrm{Ca}^{2+}$ or during a second stimulation could not be attributed to the run-down of the cell preparation, as insulin responses to early and late first $\mathrm{Ca}^{2+}$ stimulation were identical. Nor could it be explained by depletion of secretory granules, since insulin secretion during $30 \mathrm{~min}$ of high- $\mathrm{Ca}^{2+}$ stimulation did not exceed $10 \%$ of total insulin content. Rather, a desensitization of the secretory machinery to $\mathrm{Ca}^{2+}$ seems to occur. However, it should be emphasized that $\mathrm{Ca}^{2+}$ effects were never completely abolished within $30 \mathrm{~min}$ of perfusion, in contrast with results obtained with permeabilized islets (Jones et al., 1989, 1992). This difference could be due, at least in part, to the 10 times higher fold increase in insulin secretion elicited by $\mathrm{Ca}^{2+}$ in $\alpha$-toxin-permeabilized HIT cells. A small residual increase in insulin secretion was therefore easily detectable. Alternatively, high-voltage discharge could have untoward effects on pancreatic islets. 
It has been suggested that oscillations of $\mathrm{Ca}^{2+}$ could be more efficient in triggering insulin secretion than is a sustained elevation of $\mathrm{Ca}^{2+}$ (Hellman et al., 1992). Since $\alpha$-toxin-permeabilized HIT cells are highly responsive to $\mathrm{Ca}^{2+}$, we were able to test this hypothesis in our perfusion system. An important finding was that regular pulses of high $\mathrm{Ca}^{2+}$ produced phasic pulses of insulin secretion. This clearly demonstrates that oscillations of $\mathrm{Ca}^{2+}$ can trigger oscillations of insulin secretion, independent of oscillations in NAD(P)H, ATP or other metabolic coupling factors (Pralong et al., 1991; Longo et al., 1991). Nevertheless, this does not exclude an essential role for oscillations of these factors in the generation of pulsatile secretion from intact cells.

The oscillatory secretion persisted throughout the experiment, but the peak rates gradually decreased, as did the response triggered by the sustained elevation of $\mathrm{Ca}^{2+}$. Considering that total insulin secretion was 2 times lower when $\mathrm{Ca}^{2+}$ was oscillating, these results reinforce the view of a true desensitization to $\mathrm{Ca}^{2+}$, which is not due to the depletion of a particular pool of secretory granules. These observations also suggest that the so-called 'desensitization to $\mathrm{Ca}^{2+}$ ' corresponds to a decrease in the maximal $\mathrm{Ca}^{2+}$-induced insulin secretion, rather than to an impaired capacity of responding to $\mathrm{Ca}^{2+}$ changes. The decrease in peak insulin secretion from pulse to pulse was not modified by increasing the pulse interval, at least up to $14 \mathrm{~min}$. These results indicate that the mechanism involved in the desensitization to $\mathrm{Ca}^{2+}$ is rapidly activated upon the rise in $\mathrm{Ca}^{2+}$ and is operative for a long time after $\mathrm{Ca}^{2+}$ has returned to the basal level. The CaM kinase II, recently identified also in pancreatic islets and RINm5F cells (Urquidi and Ashcroft, 1993), could be involved in the desensitization process. Indeed, upon binding of $\mathrm{Ca}^{2+} /$ calmodulin, CaM kinase II is autophosphorylated, leading to a $\mathrm{Ca}^{2+}$-independent activated state of the kinase (Tokumitsu et al., 1990). Dephosphorylation by phosphatases is then required for kinase inactivation (for review, see Hanson and Schulman, 1992). However, inhibition of CaM kinase II by $\mathrm{KN}-62$ before $\mathrm{Ca}^{2+}$ application did not prevent desensitization to $\mathrm{Ca}^{2+}$. In agreement with these results, Jones et al. (1992) recently reported that desensitization to $\mathrm{Ca}^{2+}$ does not require the presence of ATP during the first $\mathrm{Ca}^{2+}$ pulse. Thus CaM kinase II autophosphorylation does not seem to be the cause of $\mathrm{Ca}^{2+}$-induced desensitization to $\mathrm{Ca}^{2+}$.

An intermediate $\mathrm{Ca}^{2+}$ concentration $(2 \mu \mathrm{M})$ produced a stable increase in insulin secretion, the level of which was close to that observed 20 min after high-Ca ${ }^{2+}$ stimulation. Since $\mathrm{Ca}^{2+}$-induced desensitization was observed at high, but not intermediate, $\mathrm{Ca}^{2+}$ concentration, this process could be due to the unphysiologically high $\mathrm{Ca}^{2+}$ concentration reached in the cytoplasm. However, there are at least two reasons to think that this process occurs under physiological conditions. First, Ämmälä et al. (1993) recently reported that desensitization to $\mathrm{Ca}^{2+}$ occurred within seconds during application of trains of voltage-clamp $\mathrm{Ca}^{2+}$ currents. These authors also provide evidence that the $\left[\mathrm{Ca}^{2+}\right]_{1}$ beneath the plasma membrane reaches much higher levels than those reported by microfluorimetric techniques. Second, in mouse pancreatic islets depolarized with high $\mathrm{K}^{+}$in the absence of glucose, despite a stable elevation of $\left[\mathrm{Ca}^{2+}\right]_{i}$, the time course of insulin secretion was very similar to that observed with high $\mathrm{Ca}^{2+}$ in permeabilized cells (Gembal et al., 1993). However, in the presence of even low concentrations of glucose, a sustained second phase of insulin secretion appeared. Therefore, glucose seems to alleviate the densensitization to $\mathrm{Ca}^{2+}$ occurring in glucose-deprived pancreatic islets.

The dynamic effects of GTP and its poorly hydrolysable analogues provide some more information about their mode of action. A $\mathrm{Ca}^{2+}$-independent stimulatory effect of GTP[S] has previously been described in a variety of cell types (for review, see Burgoyne and Morgan, 1993). In insulin-secreting cells, this effect could clearly be dissociated from activation of phospholipase C, protein kinase C and protein kinase A (Vallar et al., 1987; Regazzi et al., 1989). In the present study, we show that this effect of GTP[S] was of slow onset and remained stable throughout the experiment. This argues for a progressive activation of GTP-binding protein(s) (G-protein) by slow exchange of endogenous guanine nucleotides with GTP[S] (Gilman, 1987). These findings also suggest that GTP[S] activates a stimulatory G-protein, the nature of which is unknown. It has been proposed that an as-yet unidentified heterotrimetric G-protein, termed $G_{E}$, could control a distal step of exocytosis (Gomperts, 1990; Ullrich and Wollheim, 1988). On the other hand, small GTP-binding proteins might also be involved in the control of exocytosis in insulin-secreting cells (Regazzi et al., 1992; Li et al., 1993a,b). However, GTP[S] seems to inhibit, rather than stimulate, processes controlled by small G-proteins, such as vesicular transport from the endoplasmic reticulum to the Golgi apparatus (Rothman and Orci, 1992). Therefore, GTP[S] was thought to interfere with the presumed cycling between membrane-bound and soluble form of these proteins. If this hypothesis is correct, the stimulatory effect of GTP[S] is best explained by activation of the putative trimeric $\mathrm{G}_{\mathrm{E}}$.

There is no doubt that GTP increased peak $\mathrm{Ca}^{2+}$-induced insulin secretion in the present study. This may indicate that $\mathrm{Ca}^{2+}$ effects are accompanied by GTP hydrolysis and that GTP could be rate-limiting for exocytosis, at least in permeabilized cells. We also observed that $10 \mathrm{~min}$ perfusion with GTP[S] strongly inhibited the subsequent $\mathrm{Ca}^{2+}$-induced insulin secretion, confirming the small inhibitory effect of GTP[S] and $\mathrm{p}[\mathrm{NH}] \mathrm{ppG}$ seen in static incubations. The difference in the degree of inhibition between static and dynamic experiments is most probably due to the slow onset of GTP[S] effects, rather than to a difference in permeabilization efficiency. Indeed, despite differences in Trypan Blue uptake between plated cells and cells in suspension, pores generated by $\alpha$-toxin are of constant diameter because of their mode of formation (cf. the Introduction). Accordingly, simultaneous addition (as in static incubations) of GTP[S] and $\mathrm{Ca}^{2+}$ to the perfusion medium resulted in only slight inhibition of $\mathrm{Ca}^{2+}$-induced insulin secretion (results not shown). In other cell types, GTP[S] either stimulates or inhibits $\mathrm{Ca}^{2+}$-induced exocytosis (for review, see Holz et al., 1992; Burgoyne and Morgan, 1993). The inhibition of $\mathrm{Ca}^{2+}$ induced insulin secretion by GTP[S] in $\alpha$-toxin-permeabilized HIT cells is reminiscent of the ability of inhibitory neurohormones (acting via pertussis-toxin-sensitive G-proteins) to abolish $\mathrm{Ca}^{2+}$-ionophore-induced insulin secretion from intact cells and to attenuate $\mathrm{Ca}^{2+}$-induced insulin secretion from permeabilized cells (Jones et al., 1987; Ullrich and Wollheim, 1988; Ullrich et al., 1990). This effect of GTP[S] is thus probably mediated by inhibitory G-proteins (possibly of the $G_{i} / G_{o}$ family). However, GTP[S] induced simulation rather than inhibition of $\mathrm{Ca}^{2+}$-induced insulin secretion in electropermeabilized RINm5F cells (Vallar et al., 1987). These results are not necessarily contradictory, since GTP[S] is a non-selective activator of many G-proteins. Its effect will thus depend on the balance between stimulatory and inhibitory actions of G-proteins, whose level of expression varies between cell types (Birnbaumer, 1990).

In conclusion, in $\alpha$-toxin-permeabilized HIT-T15 cells, oscillations of insulin secretion are tightly linked to oscillations of $\left[\mathrm{Ca}^{2+}\right]_{1}$. Even a short rise in $\mathrm{Ca}^{2+}$ induces prolonged desensitization of the secretory machinery to $\mathrm{Ca}^{2+}$, resulting in decreased amplitude of the protracted insulin secretion. Thus, pulsatile addition of $\mathrm{Ca}^{2+}$ does not avoid desensitization, sug- 
gesting that, in addition to $\left[\mathrm{Ca}^{2+}\right]_{\mathrm{i}}$, other factors are required for optimal insulin secretion in intact cells. Activation of G-proteins exert a bimodal influence on insulin secretion: a $\mathrm{Ca}^{2+}$-independent stimulation and an inhibition at a step distal to $\mathrm{Ca}^{2+}$ activation of the secretory process.

We thank Ms. A.-S. Annen and C. Bartley for technical assistance. We are also grateful to Dr. R. Regazzi and Dr. J. Lang for helpful discussions. This work was supported by Grant 32-32376.91 (to C.B.W.) from the Swiss National Science Foundation and by the Deutsche Forschungsgemeinschaft Grant SFB 311 (to M.P. and U.W.). J-C. J. is 'Aspirant' of the Fonds National de la Recherche Scientifique of Belgium.

\section{REFERENCES}

Ahnert-Hilger, G., Bhakdi, S. and Gratzl, M. (1985) J. Biol. Chem. 260, 12730-12734 Ahnert-Hilger, G., Mach, W., Föhr, K. J. and Gratzl, M. (1989) Methods Cell Biol. 31, $63-90$

Ahnert-Hilger, G., Wegenhorst, U., Stecher, B., Spicher, K., Rosenthal, W. and Gratzl, M. (1992a) Biochem. J. 284, 321-326

Ahnert-Hilger, G., Dayanathi, G., Spicher, K. and Nordmann, J. J. (1992b) Biosci. Rep. 12, $463-469$

Ämmälä, C., Eliasson, L., Bokvist, K., Larsson, O., Ashcroft, F. M. and Rorsman, P. (1993) J. Physiol. (London) 472, 665-688

Bader, M. F., Thierse, D., Aunis, D., Ahnert-Hilger, G. and Gratzl, M. (1986) J. Biol. Chem. 261, 5777-5783

Bergsten, P. and Hellman, B. (1993) Diabetes 42, 670-674

Bhakdi, S. and Tranum-Jensen, J. (1987) Rev. Physiol. Biochem. Pharmacol. 107, 147-209

Bhakdi, S. and Tranum-Jensen, J. (1991) Microbiol. Rev. 55, 733-751

Birnbaumer, L. (1990) Annu. Rev. Pharmacol. Toxicol. 30, 675-705

Burgoyne, R. D. and Morgan, A. (1993) Biochem. J. 293, 305-316

Gembal, M., Detimary, P., Gilon, P., Ga0, Z. Y. and Henquin, J. C. (1993) J. Clin. Invest.

91, $871-880$

Gilman, A. G. (1987) Annu. Rev. Biochem. 56, 615-649

Gilon, P. and Henquin, J. C. (1992) J. Biol. Chem. 267, 20713-20720

Gomperts, B. D. (1990) Annu. Rev. Physiol. 52, 591-606

Hanson, P. I. and Schulman, H. (1992) Annu. Rev. Biochem. 61, 559-601

Hellman, B., Gylfe, E., Grapengiesser, E., Lund, P.-E. and Marcström, A. (1992) in Nutrient Regulation of Insulin Secretion: Cytoplasmic Calcium and Insulin Secretion (Flatt, P. R., ed.), pp. 213-246, Portland Press, London

Herchuelz, A., Pochet, R., Pastiels, C. and Van Praet, A. (1991) Cell Calcium 12, 577-586 Holz, R. W., Bittner, M. A. and Senter, R. A. (1992) Methods Enzymol. 219, 165-178
Jones, P. M., Stutchfield, J. and Howell, S. L. (1985) FEBS Lett. 191, 102-106 Jones, P. M., Fyles, J. M., Persaud, S. J. and Howell, S. L. (1987) FEBS Lett. 219, 139-144

Jones, P. M., Persaud, S. J. and Howell, S. L. (1989) Biochem. Biophys. Res. Commun. 162, 998-1003

Jones, P. M., Persaud, S. J. and Howell, S. L. (1992) Biochem. J. 285, 973-978

Knight, D. E., von Grafenstein, H. and Athayde, C. M. (1989) Trends Neurosci. 12. $451-458$

Kornberg, A. (1955) Methods Enzymol. 1, 441-443

Li, G., Hidaka, H., and Wollheim, C. B. (1992) Mol. Pharmacol. 42, 489-498

Li, G., Regazzi, R., Balch, W. E. and Wollheim, C. B. (1993a) FEBS Lett. 327, 145-149

Li, G., Ragazzi, R., Roche, E. and Wollheim, C. B. (1993b) Biochem. J. 289, 379-385

Lind, I., Ahnert-Hilger, G., Fuchs, G. and Gratzl, M. (1987) Anal. Biochem. 164, 84-89

Longo, E. A., Tornheim, K., Deeney, J. T., Varnum B. A., Tillotson, D., Prentki, M. and Corkey, B. (1991) J. Biol. Chem. 266, 9314-9319

Opara, E. C., Atwater, I. and Go, V. L. (1988) Pancreas 3, 484-487

Palmer, M., Jursch, R., Weller, U., Valeva, A., Hilgert, K., Kehoe, M. and Bhakdi, S. (1993) J. Biol. Chem. 268, 11959-11962

Pralong, W.-F., Bartley, C. and Wollheim, C. B. (1990) EMBO J. 9, 53-60

Pralong, W.-F., Gjinovci, A. and Wollheim, C. B. (1991) Diabetes 40 (suppl. 1), 80A

Praz, G. A., Halban, P. A., Wollheim, C. B., Blondel, B., Strauss, A. J. and Renold, A. E. (1983) Biochem. J. 210, 345-352

Prentki, M., Janjic, D. and Wollheim, C. B. (1983) J. Biol. Chem. 258, 7597-7602

Regazzi, R., Li, G., Ullrich, S., Jaggi, C. and Wollheim, C. B. (1989) J. Biol. Chem. 264 9939-9944

Regazzi, R., Li, G., Deshusses, J. and Wollheim, C. B. (1990) J. Biol. Chem. 265, 15003-15009

Regazzi, R., Vallar, L., Ullrich, S., Ravazzola, M., Kukuchi, A., Takai, Y. and Wollheim, C. B. (1992) Eur. J. Biochem. 208, 729-737

Rothman, J. E. and Orci, L. (1992) Nature (London) 355, 409-415

Santos, R. M., Rosario, L. M., Nadal, A., Garcia-Sancho, J., Soria, B. and Valdeomillos, M. (1991) Pflügers Arch. 418, 417-422

Sillén, L. J. and Martell, A. E. (1964) Stability Constants of Metal Ion Complexes, 2nd edn., Special Publication 17, The Chemical Society, London

Theler, J. M., Mollard, P., Guérineau, N., Vacher, P., Pralong, W. F. Schlegel, W. and Wollheim, C. B. (1992) J. Biol. Chem. 267, 18110-18117

Tokumitsu, H., Chijiwa, T., Hagiwara, M., Mizutani, A., Terasawa, M. and Hidaka, H. (1990) J. Biol. Chem. 265, 9437-9440

Ullich, S. and Wollheim, C. B. (1988) J. Biol. Chem. 263, 8615-8620

Ullrich, S., Prentki, M. and Wollheim, C. B. (1990) Biochem. J. 270, 273-276

Urquidi, V. and Ashcroft, S. J. H. (1993) Diabetologia 36 (suppl. 1), A113

Valdeomillos, M., Santos, R. M., Contreras, D., Soria, B. and Rosario, L. M. (1989) FEBS

Lett. 259, 19-23

Vallar, L., Biden, T. J. and Wollheim, C. B. (1987) J. Biol. Chem. 262, 5049-5056

Wollheim, C. B. and Pozzan, T. (1984) J. Biol. Chem. 259, 2262-2267 